\author{
Ж.С. Сандыбаев ${ }^{1}$, С.У. Абжалов ${ }^{2}$ \\ 1Нұр-Мүбарак университеті, Қазақстан, Алматы қ., e-mail: kaz_astana74@mail.ru \\ ${ }^{2}$ Қожа Ахмет Ясауи атындағы Халықаралық қазақ-түрік университеті, \\ Қазақстан, Түркістан қ.

\section{ӘА-ФАРАБИАІН ФИАОСОФИЯСЫНААҒЫ «БІРІНШІ БАСШЫ» КОНЦЕПЦИЯСЫ}

\begin{abstract}
Мақала әл-Фараби философиясындағы билеуші тұжырымдамасына арналған. Ойшылдың пайымдауынша, ізгі қаланың билеушісі «имам» да, «философ» (ғалым) та болуы керек, өйткені олар тек қоғамды басқаруға шақырылған дарынды адамдар.

Билеуші, әл-Фарабидің пікірінше, ерекше интелмект пен керемет аАами қасиеттерге ие таңдалған адам. Ғалым ретінде ол адамдар туралы қарапайым білімдермен ғана шектелмейді. Сонымен қатар, билеуші өз білімін бейнелі түрде жеткізе білуі керек және қала тұрғындарын бақытқа жетелейді. Осы мақсатта ол нағыз билеушіні бір нәрсе туралы ойлау керек деп санайды бұл қала тұрғындарын көптеген жылдар бойы алаңдатып келеді. Әл-Фараби философиясындағы правитель туа біткен қасиеттерге ие, мысалы: ақиқатты сүю, әділеттілік, жақсылықты өз бетімен орындау, ар-намыс, өтірікке деген жеккөрушілік, жағымпаздық, және т.б.

Әл-Фарабише бірінші басшы болуға мына жолдармен жетуге болады: алғашында аламда бәйекшіл ақыл-парасат, сонсоң онда жүре келе қалыптасатын ақыл-парасат пайда болады, осылан кейін Аристотельдің «Жан туралы» кітабында суреттелгендей, әрекетшіл ақыл-парасатпен қосылады. Мұндай адамды ертедегілер нағыз әкім деп атаған.

Авторлардың пікірінше, әл-Фараби қалаған бақытты қоғамның логикасы басқару өнерінде, білім мен әдістерде жатыр, бұл туралы оның шығармаларында көп айтылады. Ғалым жетекшісінің бейнесі мысал бола алады. Бұрынғыдай, мемлекеттік басқаруды, билік жүйесін жетілдіріп, қоғам мүшелеріне жақсылықты ұялату қажет.
\end{abstract}

Түйін сөздер: әл-Фараби, бірінші басшы, қоғам, бақыт, философ.

\author{
Zh.S. Sandybayev', S.U. Abzhalov² \\ ${ }^{1}$ Nur-Mubarak University, Kazakhstan, Almaty, e-mail: kaz_astana74@mail.ru \\ ${ }^{2}$ Khoja Akhmet Yassawi International Kazakh-Turkish University, \\ Kazakhstan, Turkestan
}

\title{
The concept of a ruler in the philosophy of al-Farabi
}

The article is devoted to the concept of the Ruler in the philosophy of al-Farabi. The Thinker argues that the Ruler of a virtuous city must be both an "imam", a "philosopher" (scientist), because only they are gifted people who are called to rule society.

The ruler, according to al-Farabi, is a chosen person with a special intellect and wonderful human qualities. As a scientist, he is not limited to simple common knowledge about the people. Also, the ruler should be able to figuratively convey in words his knowledge and guide the inhabitants of the city to happiness. To this end, he believes that the true Ruler should be concerned about one thing - this is concern for the inhabitants of the city for many years. The pratitel in the philosophy of al-Farabi has innate qualities, such as love of truth, justice, selfless fulfillment of good, honor, hatred of lies, contempt for flattery, etc.

Al-Farabi's first leadership can be achieved in the following ways: first in man there is a sublime intellect, then in him there is a progressive intellect, and then, as described in Aristotle's book On the Soul, there is an active intellect. Such a person was called a real akim by the ancients.

According to the authors, the logic of a happy society, which al-Farabi so craved, lies in the art of management, knowledge and methods, about which so much is said in his works. The image of a scientist leader is an example. As before, it is tirelessly necessary to improve public administration, the system of power, and instill good in members of society.

Key words: Al-Farabi, first leader, society, happiness, philosopher. 


\author{
Ж.С. Сандыбаев ${ }^{1}$, С.У. Абжалов² \\ 'Университет Нур-Мубарак, Казахстан, г. Алматы, e-mail: kaz_astana74@mail.ru \\ ${ }^{2}$ Международный казахско-турецкий университет им. Ходжа Ахмеда Ясави, \\ Казахстан, г. Туркестан
}

\title{
Концепция о правителе в фимософии аль-Фараби
}

Статья посвящена концепции Правителя в философии аль-Фараби. Мыслитель утверждает, что Правитель добродетельного города должен быть одновременно «имамом», «философом» (ученым), ибо только одаренные люди призваны управлять обществом.

Правитель, согласно аль-Фараби, - избранная личность с особым интелмектом и прекрасными человеческими качествами. Будучи ученым, он не ограничивается простыми распространенными знаниями о народе. Также правитель должет уметь образно передавать словами свои знания и направлять жителей города к счастью. А^я этого он считает, что истинного Правителя должно беспокоить одно - это забота о жителях града на долгие годы. Правитель в философии альФараби имеет врожденные качества, такие как любовь к правде, справедливость, бескорыстное совершение добра, честь, ненависть ко ^жи, презрение к лести и т.А.

Аидерство по аль-Фараби может быть достигнуто следующими способами: сначала у человека Аолжен быть возвышенный интемлект, затем проявляется прогрессивный интемлект, а затем, как описано в книге Аристотеля «О душе», образуется активный интемлект. Такого человека древние называли настоящим акимом.

По мнению авторов, могика счастливого общества, которого так жаждал аль-Фараби, заключается в искусстве управления, знаниях и способах, о которых так много сказано в его трудах. Образ мидера-ученого является примером. По-прежнему, неустанно необходимо совершенствовать государственное управление, систему власти, прививать добро членам общества.

Кмючевые слова: аль-Фараби, правитель, общество, счастье, философ.

\section{Кіріспе}

Әл-Фараби - ұлы ойшыл, дара тұлға. Оның ғылым үйренуге және философиялық ойларға терең қызығушылығының қалай пайда болғанын нақты айту қиын. Ғалымның білімге қызығушылығы Бағдат шаһарына келуінен бұрын бар болған деседі. Кейбір деректерде жас ғалымның философиялық ілімдерге махаббаты грек ойшылы Аристотельдің трактаттарын оқып, зерделеу барысында пайда болды, кейін бүкіл өмірін толықтай білімге арнады деген мәліметтер айтылады. Енді бір деректерде әл-Фарабидің аз уақыт қазылық қызмет жасағандығы, сосын білімге қызығушылығы артып, қызметінен бас тартып ғұмырын білімге арнағаны жайында әңгімелер кездеседі. Анығы, әл-Фараби - артынан өшпес i3, сарқылмас мұра қалдырған дарынды тұлға, екінші ұстаз, ұлы комментатор.

Ғалым жайында айтылған өмірлік оқиғалар мен бізге дейін жеткен ғылыми трактаттары әл-Фарабидің жүйелі және тынымсыз ғалым іздену үстінде өмір сүргенін көрсетеді. ӘлФарабидің философиялық тұлғасына қатысты библиографиялық деректерде оның негізінде грек философтардың ішінде Аристотельге жиі сілтеме жасайтындығы байқалады. Мысалы, бұған қатысты мынадай әңгіме бар. Бір күні адамдардың бірі ғалымнан:
- «Сіз білімдісіз бе әлде Аристотель ме?», деп сұраған екен.

Сонда ойшыл:

1. - «Егер мен сол заманда өмір сүрген болсам, оның ең алдыңғы қатарлы шәкірті болатын едім», - деп парасаттылықпен жауап берген екен (Yaşar Aydınlı, 2017: 13).

Ғалымның бұл жерде «ең алдыңғы қатарлы шәкірті болатын едім» дегені, оның Аристотелдің ой-тұжырымдарын өте жақсы түсінетіндігін білдіреді. Біз ойшылдың парасаттылығымен бірге кішіпейілдік, көрегенділік және әдептілігін байқаймыз. Ортағасырлық философтарына тән әл-Фараби де Аристотельдің шығармашылығымен терең танысты, көп зерттеді. Тіпті Аристотельді көп зерттеп, оның шығармаларын араб тіліне аударып, талдап, оларға түсініктеме жазғаны сонша, ол «ұлы коментатор» атанды. Бұл, ғалымның грек ойшылдарын, әсіресе Аристотельді зерттеуге көп ыждаһат танытқанын көрсетеді.

Аристотельдің «Китаб ән-нәфс» (книга о душе) атты шығармасының бір қолжазба нұсқасының шетінде әл-Фарабидің: «Бұл кітапты екі жүз рет оқыдым» деп қалдырған сөздерінің бар екенін ғалымдар жақсы біледі. Дәл сол сияқты басқа жерде Аристотельдің «Ас-Симаут-Табии» атты шығармасын қырық рет оқығандығы және тағы оку керектігін айтқандығы мәлім. 
Ұлы ойшыл көптеген теориялық ғылымдар жайындағы еңбектердің авторы. Мысалы, оның «Азаматтық саясат», «Бақытқа жету жайында», «Қайырымды қала тұрғындарының көзқарасы», «Азаматтық қоғам» жайында жазылған еңбектері және сол сияқты т.б. шығармалары көпке танымал. Ғалым өзінің бірінші басшы, билік, мемлекеттік басқару, бақытты қоғам құру секілді ойларын негізінен осы шығармаларында баяндайды.

2. Әл-Фараби өзінің еңбегінде бірінші басшыға «имам» деген сөзді қолданса, басқа жерлерде «патша», «әкім», «философ» деген сөздермен де атайды (Әл-Фараби, 1995: 102).

Әл-Фараби ұсынатын пікірі бойынша, патша қоластындағы жұртшылықтың жетекшісі ретінде, оларды тәрбиелеу мақсатында өтімді сөздер қолдануға және қажетті жағдайда күш қолдануға да құқылы.

Сол сияқты әл-Фараби қала тұрғындарын, қоғамды тәрбиелеуде, адамгершілік қасиеттерді қалыптастыруда және оны сақтауда патшаның орны маңызды екендігін көрсетеді. Әл-Фараби тәрбиелеудің негізгі екі әдісін ұсынады:

1) Ғылымға икемі бар, оку, білім арқылы, сауатын ашу арқылы ерікті түрде тәрбиелеу әдісі;

2) Ғылым-білімге қарсы келетін, қабылдамайтындарға күштеу әдісін қолдануды ұсынады.

Сонымен қатар, қоғамды тәрбиелеу ісінде өнерлі, қайырымды, сауатты мамандарды жұмылдыру қажеттілігін насихаттайды.

Әл-Фараби «сонда абсолюттік мағынада бірінші басшы деген кім?» деген сауалға, былай жауап береді: бірінші басшы басқа біреудің басшылығына мұқтаж емес, оның білімдарлығының жоғарылығы соншалықты, өзіне жөн сілтейтін, өзіне билік жүргізетін адамға мүлдем қажеттілігі жоқ, жан-жақты жетілген адам. Алдағы уақытта болатын жағдайларды егжей-тегжей біліп отыратын қабілеттің болуы оған шарт емес. Ол үшін оның қасында көмекшілері бар. Басшы басқаларға жақсы басшылық қылуға шебер әрі қабілетті. Қарамағындағы адамның не нәрсеге бейім екенін және оны қалай пайдалану тиімді екенін біледі (Әл-Фараби, 1996: 127).

Сондай-ақ, басшы бақытқа жеткізетін жоспарды белгілейді, сол үшін басқаларға дұрыс бағыт сілтей алады. Бірақ, мұндай қабілет кез келген адамның бойында жоқ, ол жаратылысы ерекше, бойында көркем қасиеттері бар адамдарға, яғни ақылымен, парасатымен ерекшеленетін адамдарға ғана тән болады.

1. Әл-Фарабидің ойынша, адамдыққа ықпал ететін нәрселер - тапқырлық, табандылық қасиеттері, адамның ой-санасын, ақыл-парасатын жетілдіру. Бұл азаматтық философияның мәселелері болса, сол өнерді сақтай алу мүмкіндігіне жеткізетін қағидаларды орнықтыру саяси философияға жатады. Ізденіс, білім алу адамдыққа жету жолы болмақ. Адам қалыптасуы біртіндеп, сатылап жетілуі арқылы жүзеге асады. Адам өз болмысын, қағидаларын ізденіс-білім арқылы және үнемі моральдік құндылықтарды үйлестіре отырып меңгереді (Yaşar Aydınlı, 2017: 13).

Әл-Фарабидің айтуынша, азаматтық философиясының негізгі қарастыратын мәселесі - адам болмысының беретін жемістері, яғни адамның адамгершілік қасиеттері негізінде туындайтын сапалары, түрлері, адамды қинайтын рухани дерттерден құтылудың жөн-жобасы, адамды азғындыққа салатын түрлі жағдайлар мен келеңсіз оқиғалардан сақтана білу. Азаматтық философияның көмегімен бақытқа жетелейтін жолдарды тануға болады, ақыл-парасаттың арқасында ізгі істерді жасау мүмкіндіктерін арттыруға болады. Бұл екі әрекеттің түрі адам болмысын куаттауға бағытталады. Өз ойсанасын, болмысын нығайту арқылы адам баласы өз болмысын жетілдіре түседі, соған жол ашады. Адам ақылы мен парасатын арттыруға ұмтылмаса, бақытқа жете алмайды. Бақыт деген не екенін ұқпаған адамның әрекеті оңалмайды.

Ғалымның пайымынша, азаматтық қоғамды басқаратын басшының бойында ақыл-парасаты мол болуы қажет. Себебі ондай басшы өз еліндегі, қоғамдағы болып жатқан түрлі құбылыстарды байқап, солардың себеп-салдарын аңғарып, шешімдерін табуға әрекет қылады. Сол мәселелерді айқындай білу, көптеген қиындықтардан құтылуға мүмкіндік береді. Ақыл саналы түрде игілікке жету жолдарын сыни көзбен сараптап, ортақ мүдде үшін қызмет қылады. (Yaşar Aydınlı, 2017: 13).

Адамның бойындағы ерекше қабілеті, ол - ақыл мен парасат. Ақыл-парасаттың бар болуының арқасында мақсаттар туындайды, мақсатқа жетудің жолдары айқындалады, оған жету үшін қажетті құралдар қолданылады.

Осындай ерекше қабілеттерді икемдеген ақыл адамға қажетті, оны емдейтін тәсілдерді қамтуға мүмкіндік береді. Өз мүмкіндіктерін, қабілеттерін шыңдап, дамыта алатын адам, өзгелермен де бірлесіп, ұйымдаса алады. Өз сөзіне, іс-әрекетіне толық жауап бере алатын адам өзіне де, өзгелерге де билігін жүргізе алады. Ізгі, өнегелі амалдарда адамның көңілінде білім мен талаптар ұштасады - деп есептеген 
әл-Фараби - алғашқы ілімдер қалайша, неліктен қалыптасты, олар неліктен көздеулі, арнайы бағытты сипатқа ие болды? деген сұрақ қойып, кейін өзі бұл сауалға жауап іздеді (Әл-Фараби, 1995: 102)

Ақыл түрлі мәселелер мен міндеттерді таниды, түсінеді, саралайды, білген нәрселерін туралық, жақсылық жолында қолданады, осы бағытта аянбай әрекет қылады. Ақыл қажеттіліктерді анықтау, білу арқылы, соған қарай байыппен әрекет жасайды. Әрекетті куаттап, әлдендіру үшін сенімге жүгінудің, ақыл-ойға жүгініп әдісайла қолданудың артықшылықтары мол.

Ақыл-парасаттың аясын көркем мінез-құлық, игі істер, адал амал-әрекеттер құрайды. Біржағы өз қабілетімізді, мүмкіндіктерімізді өнер түріне айналдыруға талпынамыз, біржағынан екі түрлі өнерге - көркемдік өнері мен пайдаға кенелу өнеріне жеткіміз келеді деп пайымдаған ойшыл, ақыл мен парасат - болмыс пен сананы, адам мен елді басқаруда ортақ мәселені көтереді деп сенген. Ең алдымен басшыға елді басқарып, оларды бақытқа жеткізу үшін аян қажет деп есептеген.

«Әрекетшіл ақыл-парасаттан бәйекшіл ақылпарасатқа күш берілген уақытта адам заттар мен әрекеттерді анықтап, соларды бақытқа жету жолына бағдарлап алуына ықпал ететін күш осы кезде туындайды. Әрекетшіл ақыл-парасат және бәйекшіл ақыл-парасаттың арақатынасы осылай жүзеге асса, сонымен қатар бұған жүре келе біртіндеп қалыптасатын ақыл-парасат септігін тигізсе, уахи сол кезде болады» (Нысанбаев, и др., 2009:656). Әл-Фарабидің бұл жерде айтпақшы болған нәрсесі, әрекетшіл ақылпарасат бәйекшіл ақыл-парасатқа жоғарыдан күш дарыған уақытта, адам бақытқа жетуіне қажетті нәрселерді анықтап, алдына бағытбағдар белгілейді. Ал бұған тағы да жүре келе қалыптасатын ақыл-парасат келіп біріксе, сонда адамға аян келеді демек.

Себебі ғалымның айтуынша әрекетшіл ақыл-парасат алғашқы себептің болмысынан шығатындықтан, әрекетшіл ақыл-парасат арқылы адамға аян келуі бірінші себептің өзі деп пайымдауға болады. Осы адамның басшылығы бірінші басшылық болады, ал қалған барлық адамдардың басшылығы бірінші басшылыққа салыстырмалы түрде қарағанда, одан кейінгі және біріншіден шығатын басшылық болады. Бұл анық нәрсе. Жалпы халық арасында «Патша Құдайдың жердегі өкілі» деген түсінік осындай түсініктен қалыптасса керек. Себебі әл-Фараби айтып отырғандай бірінші басшыға билік аян арқылы Бірінші себепкерден келеді.
1. Осындай басшылыққа бойұсынған адамдар қайырымды, жетістікке жеткен және бақытты адамдар болады. Егерде осындай адамдар халық болып ұйымдасса, осындай халық қайырымды халық болады, ал егер бұл адамдар барлығына ортақ аймақтарға қоныстанып ұйымдасса, бұл жағдайда да осындай басшымен бірлескен адамдар қоныстанған аймақта қайырымды қалаға айналады. Ал егерде олар бір қонысқа шоғырланбай, әр жерге бөлектеніп қоныстанатын болса және олар, сол аймақтың тұрғындары осындай басшыға емес, кереғар, басқа басшыға бағынатын болса, ондай жағдайда бұл аймақтардағы қайырымды адамдар адасушы болады (Сандыбаев, 2001: 102 ).

Өйткені халық жоғарыдан аян келіп, сонымен бағдар жасап жүретін басшыға бағынбай отыр.

Ғалымның айтуынша ондай адасқан халықтың бытыраңқы болуына бірнеше себеп бар. Олар: әділ басшыға бағындайды немесе бір жерде бірігіп тұратын қайырымды қала дегенді білмейді немесе әлі ондай қоғамды көрмеген. Сол сияқты бұрын халық болып, бір қалада тұрса да бақытсыздыққа ұшыраған немесе оларға жау шапқан болуы мүмкін яки болмаса қатты қудалауға түскен немесе бір аты жаман індетке ұшырап жан-жаққа қоныс аударған.

2. Әл-Фараби басшының тұла бойында бұрыс, бұзақы мінездің болмау керектігін айтады. Жаман мінез-құлық - жақсы іспен шұғылдануға ықпалын тигізбейді. Жаман мінез-құлық түсінік қоспайды, дұрыс пен бұрыстың, жақсылық пен жамандықтың мағыналарын ұқтырмайды. Жаман мінез-құлықта жасампаздық, қайырымдылық секілді игі қасиеттер жетіспейді, бақытқа, дәулетке апаратын жолдарды тани алмайды. Осындайда бұзық, жаман іс-әрекеттер жақсы амал жасаудан мүмкіндігі әлдеқайда басым түседі (Сандыбаев, 2001: 102).

Жаман мінездің түп-тамыры - кемшілік пен кемдікте, надандық пен жабайылықта. Бұзақы әрекеттер мен қылықтар бір-бірімен ұласып кете беретін болса, елдің құлдырап, ыдырап кетуі әбден мүмкін. Енжарлықтың қауіпті кесірі де сол, ол амал, іс-әрекетті өнер ретінде дамытуға, жүйелеуге көңіл бөлмейді, жаман әдеттерді әдейілеп әдетке айналдырып, тірліктегі тағлымды, сананы тұншықтырады.

Ұлы ойшыл «Азаматтық саясатында» мемлекетті куаттандыратын, қоғамды көтеретін қоғамның адамгершілік қасиеттері емес, олардың жүйелілігі, әлеуметтік бағыт-бағдары мен 
ұстанымдары екендігін айтады. Адамның жеке өзіндік тұлғасы, өмірдегі қабілеттері мен қасиеттерінің өзара қатынастары қоғамдағы тәртіптің, жүйеліліктің бастамасы және қозғаушы күші болмақ. Адамзат осы жүйеге, осы бастамаға және осы күшке әлеуметтік сипат беру үшін, олардың мән-мағынасын өз болмысына бағыттау үшін бар мүмкіндіктерді арттыруда және іздестіру жолында. Бұл бағытта нәтижелі әрекет үшін қажымас қайрат, ерекше құнттылық, асқан көрегенділік жетіспеуде (Сандыбаев, 2001: 103).

Әл-Фараби адамды әлдендіретін бес күшке арнайы кеңінен тоқталып өтеді - нәрлендіру, түсіндіру, елестету, ақыл және парасат. Саясиәлеуметтік бағытты толыққанды ұғыну үшін теориялық тұрғыда ізгілікті тереңінен түсіндіретін ақыли түсінікке, жағдайды адами қасиеттермен де үйлестіретін моральдық қайырымдылыққа деген қажеттілік анағұрлым артуда. Саяси өмірде, елді басқаратын басшының рухани жағдайы, жан-дүниесі шыңдалуына түсетін жүк әлдеқайда басым болады.

Ойшыл ғалым қала тұрғындары бақытқа жетуі үшін саяси өмірдің кейбір талаптарын ұсынды:

- міндетті нақты орындау;

- мақсатқа жеткізетін амалға сеніммен кipicy;

- мақсатқа бастайтын практикалық ақылпарасаттың күш-қуаты мен бойда бар қабілетті бірге жұмылдыру;

- өмір сүрудегі әлеуметтік сапаның жоғарғы дәрежесіне жетуді көксеу;

- адамдар арасындағы қарым-қатынасты жақсарту (Әл-Фараби, 1995: 102). Әл-Фарабише нағыз әкім - тұлғаның кемелді болуы, саяси өмірдің тірегі һәм қозғаушы күші.

Саясаттажетістіккежетіп, қалатұрғындарына жақсы өмір сүрулері үшін қолайлы жағдай жасаймын дейтін әкімнің көздеулі мақсаты:

- бағынышты адамның еркін бағалай білу;

- тұрғындарға еркіндік бере отырып, олардың талап-тілегін қанағаттандыру;

- өзінің жеке тілектерін қажетінше тежей білу және т.б.

Әкімдікті ұштай түсу үшін әл-Фарабиде адам қандай да бір амал жасайтын уақытта немесе шешім қабылдаған кезінде кімге еліктеу керек екенін және кімнің айтқан сөзі мен ақылына зер салуды жақсы білуі тиіс екенін алға тартты. Адамның осындай қабілеті жоғалмайды және таусылмайды. Әрекетті сақтау, жақсы мінез-құлық тәрбиелеп қалыптастыру оның басты кепілдігі. Белгілі бір жақсы іске әуестену, жақсы мінез- құлық қалыптастыру - адамды дамыту өнері мен өнегесі болмақ. Сондай-ақ, әкім басқару өнерінде адамгершілікті басшылыққа алып, орташа шама мен аралықтан аспағаны мақұл. (Әл-Фараби, 1995: 102). Әл-Фарабидің үлгісіне сәйкес әкімнің бойында мынадай қасиеттердің ұштасуы лазым: даналық, асқан пайымдағыштық, шешендік, жақсы қиялдай білу қабілеті, жорықта қолбасшы бола білу қабілеті. Ұрыс бола қалған жағдайда майданда жүріп, мемлекеттік істерді жүргізе білу қабілеті аса маңызды.

Басшы, бір мақсатқа жету үшін әртүрлі амаләрекеттерді бір-бірімен ұштастырып, онда халық үшін игілік пен ізгіліктің бар екенін көрсетіп, олардың арасындағы байланыс пен қарым-қатынасты нығайтуға үлес қосады. Ол - мінезкұлқындағы әділеттік пен қайырымдылықтан құралатын әдетке иелік етеді, тұрғындарының бақытқа жетуін өмірлік ісі етіп алады. Қала тұрғындарына осындай жағдай жасағанда, құрметтен басқа ештеңе талап етпей беретіндер әкімдердің ішінде ең қадірмендісі болып табылады.

Мысалы, әкім оларға байлық бергенде оның есесіне олардан ақы талап етпейді немесе оларды рахатқа бөлегені үшін өзіне рахат беруді талап етпейді, сөзімен де, ісімен де тек сыйлауды, мадақтауды, құрметтеуді ғана тілейді. Тұрғындардың оның атын көзі тірісінде, өлгеннен кейін де ұзақ уақыт ұмытпай, қадірлеуін ғана қалайды.

Әл-Фарабише әкімнің басты мақсаты қара басының құрметке беленуі, байлыққа ие болуы, ләззат алуы емес, керісінше тұрғындарды бақытқа жетелейтін жақсылықты молайту. Сонымен қатар әкім басқару өнерінде даналықты, естілік пен зеректікті, басқалардың пікірін таңдай білу, ойдың дұрыстығын дәлелдей алу қасиеттерін басшылыққа алуы тиіс. Сонда барып әкімнің мінез мен әдеті кәсіптік деңгейге көтеріледі. Ізгі қасиеттер мен бойындағы қабілетін біріктірген, заңдар мен тапа-қағидаларды ұштастыра білетін адам басшылыққа бейім демек (Әл-Фараби, 1996:4).

Әл-Фараби әкімнің басқаруын - заңды басқару деп атайды. Басқару ісіндегі негізгі мақсат - ақиқатқа жету, қала тұрғындарына қайырымдылық жасау, игі іс істеу. Әкім осындай жақсы ниетті, тілекті, амал-әрекеттегі ықыласты қала тұрғындарының әрбіріне үйретіп, үйлестіреді.

1. Жүрегі кең, ізгі, сонымен қатар ілімі, оқығаны тең болған жан «даналылық пен қайырымдылық үшін өмір сүреді». Даналықтың қалауы мен мақсатын бірге ұстану ар- 
қылы алауыздықтан арылуға болады, себебі даналықтың арқасында алауыздықтың қайнарларын кетіретін жолдарын табады. (Әл-Фараби, 1975: 368 ).

Ойшыл, тәсіл - танымның тоқтауы, дананың оқтауы деп ойын түйіндейді және тәсілден осындай қорытынды шығаруға болатындығын айтады:

- адам мінез-құлқы элементтерінің үйлесімсіздігі неғұрлым аз болса, соғұрлым теңдікке жақын болады, ал соған керісіншесі, үйлесімсіздік неғұрлым үлкен болса, соғұрлым ол теңдіктен алыс болады;

- кімде-кімнің әдеттенген іс-әрекеттері жалпы жұртшылықтың ойынша өте жақсы деген істермен үйлессе, оған әдеттегідей теориялық ғылымдарды оқып білуге және оның іс-әрекеттерін шынайы өте жақсы деп қабылдауға кедергі болмайды;

- екі адамның қалауы, мақсаттары, ниеттері бір жерге бағытталса, оларды соған жеткізетін жолдары да, құштарлықтары да бір, ортақ болады. Осындай жағдайда өзара алауыздыққа орын да қалмайды.

- ал егер, қашанда көздеген мақсаттар түрлі болса, ниеттері бөлектенсе, арада бірліктің сақталуы да екіталай. Алауыздық келісімге емес, өзімшілдікке әкеп соқтырып, жауыздыққа апарады;

- ақиқатқа ұмтылған екі адам өз мақсаттарын ұғынады, оны анық біледі, сол себепті олардың араларында қойған мақсаттары жайында көзқарастарында кереғарлық, қайшылық, алалық туындамайды. Туралық пен қайырымдылықтан ауытқыған жағдайда адам адасады;

2. Бейқамның және бейқамсынған адамның барар жері бір, өйткені бейқамдық адамды сәтсіздікке душар ететіні сияқты, бейқамсызданған адам, оның өтірік бейқамдығы сәтсіздікке апарады. Бейқамсызданған адам өзінің не нәрседе бейқамсызданып жатқанын білгенімен, бірақ бұған нені қолдану қажеттілігін білмесе, сол білгені оған ешқандай көмегін бермейді (Әл-Фараби. Әлеуметтік-этикалық трактаттар, 1975: 368 )

Әл-Фарабидің айтуынша, ізгі, қайырымды басшының басқалардан ажыратып тұратын басты ерекшелігі - басқаруды құрған, билікті жүзеге асырған адамның, яғни алғашқы басшының міндетін «Алладан келген аянмен» жүзеге асыруы. Бірінші басшыға әлеуметтік-саяси шеңберді қалыптастыру, дұрыс шараны, басқаруды ұйымдастыру құқығын беретін қабілет табиғи түрде үкім беруге негізделген қабілет болып табылады әрі бұл да уахиға байланысты. Сол себепті ғалым бірінші басшының қабілеті - оған келетін уахиға сәйкес басқарушылық. Сондықтан ол ізгі діндегі әрекеттер мен пікірлерді тек уахимен бағалап, анықтайды. Осылай әл-Фараби кейде басшылықты пайғамбарлық қызметпен ұштастырып, оның қаншалықты маңызды екенін аңғартқандай болады.

3. Әл-Фараби үшін ең үлкен бақыт дегені шынайы бақыт. Ол - дүние мен дүниелік мүдделерден асып түседі және материяға тәуелсіз өмір сүруді білдіреді. Осы мақсатқа сәйкес ұйымдастырылған қоғамдық-саяси ұйымның әділ қоғамы да осы қоғамның басшысы да әділ көшбасшы. Ғалым әділ басшыда лайық нәрсе патша, философ және пайғамбарлықты біріктіру арқылы іске аспақ деп философия мен дінді жақындастыруға қадам жасады (Әл-Фараби. Әлеуметтік-этикалық трактаттар, 1975: 368).

Мысалы, әл-Фарабише анықталуы тиіс жағдайларға қатысты барлық пікір мен амалдар бірінші басшыға аян жолымен білдіріледі. Бұл жағдай басшы тек сол амалды жүзеге асыратын миссияға ие болмақ. Өйткені оған не қылу керектігі аян болды. Сол сияқты діни-саяси жағдайды анықтаудың екінші тәсілі - бірінші басшы «Құдайдан келген аян мен жігердің арқасында шешімді өзі қабылдайды». Басшы ешқашан ақылға салмай, шешім қабылдамайды. Ғалым мұнда басшының ақылы мен қиялдай білу күшін көрсетіп, пайғамбарлық мысалмен нақтылағанын байқадық.

Негізінде әл-Фараби халыққа түсінікті болуы үшін пайғамбарлықты нақты құбылыс ретінде емес, адамның тиісті ақылымен бағаланып, анықталатын мысалы ретінде қарастырады. Бұл байланыс алғашқы басшыда дінді құрайтын әрекеттер мен көзқарастарды, яғни сенім (иман), ғибадат және қарым-қатынас қағидаларын өздеріне қарай белгілейтін шарттарды анықтау және терең түсіну шеңберінде көрегендік, дұрыс нәрсені көріп, бекіту қабілетін қалыптастырады (Әл-Фараби, 1995: 34). Осылайша, Қүдайдың қолдауымен ол ақылға қонымды әлеуметтіксаяси шараларды мейлінше жақсы жүзеге асырады.

Бірінші басшының қала тұрғындарын осы дүниеде бақытқа, ал арғы өмірдешынайы бақытқа жеткізу мақсатында іске асырған заңы - ізгі заң. Ғалым шынайы бақытқа жету бір-бірімен тығыз байланған, төрт түрлі қасиетке байланысты. Бұл - теориялық ізгілік, интеллектуалдық ізгілік, адамгершілік ізгілік және практикалық өнерге қатысты ізгілік.

1. Егер қала тұрғындары шынайы бақытты болуды көздесе, онда осы ізгіліктерді өз жағ- 
дайларына сәйкес орындаулары қажет. Бақытқа қоғам деңгейінде жетулері үшін қоғам мүшелері осыған амал қылады. Ал енді бұл ізгі қасиеттерді тұлға ретінде ең жоғары деңгейде орындаған адам - ізгі басшы болып табылады. Қала тұрғындары осындай ізгі басшының билігінің астында төрт ізгілікті бойларына сіңіруі арқылы бақытқа жетулері мүмкін. Ғалым бақытқа жету үшін жақсы басшының жеткіліксіз екенін де естен шығармайды. Өйткені халық бақытқа жетуді қалап қана қоймай, соған ұмтылуы қажет. Сол үшін басшыға бағынады (Мырзахметов, 198: 245).

Өз кезегінде мұндай басшы ер мен елдің басын қосады, ер намысы мен ел намысын қорғайды, халықты бақытты өмірге бастайды. Бұл басшыда ойшылдық ізгілік басым. Өйткені ойдағы ізгілік - ұжымды басқарудың басты шарты.

Ғалымның айтуынша, басқарудың екі түрі бар: Басқарудың бір түрі шындығында бақытқа жеткізетін әрекеттерді, мінез-құлықты, ерік қасиеттерін нығайтады және бұл ізгі басқару болып табылады. Осындай басқаруға бағынатын қалалар мен халықтар ізгі қалалар мен халықтар болып табылады. Басқарудың екінші түрі қалаларда шындығында бақыт болып табылмайтын қиялдағы бақытқа қол жеткізетін әрекеттер мен қасиеттерді нығайтады, мұндағы басқару надандық басқару болмақ. Ғалым бірінші басшыға басқарудың осы, яғни екінші түрінен сақтануына кеңес береді. Өйткені бұл басқару әдісі қала тұрғындарын жалған, қиялдағы бақытқа жетелейді.

2. Әл-Фарабидің пікірінше, адам - табиғатынан әлеуметтік және саяси жаратылыс. Сондықтан да адам басқа индивидтерге мұқтаж, басқа адамдармен өмір сүруді қажет етеді. Кез келген адам бақытты болуды қалағаны сияқты, қоғам да бақытты ұжымды қалайды. Қала қоғам мүшелерінен құралғандықтан ұжымды басқаратын жетекші қажет. Бұл жетекші қала тұрғындарын бақытқа бастайды. Ол үшін басшы халықты басқаратын және оларға тәрбие беретін білімдерді игереді: «Сондықтанда әкім белгілі бір адамды немесе халықты, бақытқа апаратын белгілі бір білім деңгейін анықтап, сол халықты ненің көмегімен тәрбиелеу керектігін есте сақтауға, сонымен қатар, сол халықты көндіру әдісімен тәрбиелеу үшін қолданатын нәрселерді білуі тиіс» (Мырзахметов, 198: 245).

3. Сонымен қатар әл-Фараби әкімдердің ішінде ізбасар әкімнің де бар екенін атап көрсетеді. Оның айтуынша егер әкімдердің бірі ертеректе өзі енгізген заңды белгілі бір уақыттан соң өзгертуді жөн көрсе, оны өзгертуі әбден мүмкін. Себебі ол қала тұрғындарының пайдасы мен мүддесін жақсы біледі. Соған сәйкес заңды да өзгертуге құқылы. Дәл сол сияқты, кейіннен келген әкім де өзінен бұрынғы әкімнің шығарған заңын өзінің билігі тұсында өзгертуге құқығы бар (Келімбетов, 1986:79).

Өйткені, одан бұрынғы әкімнің кезінде қала жағдайы басқа болуы мүмкін. Ол заңды сол уақытқа, жағдайға қарап шығарған. Ал енді ескі әкім қазіргі жағдайды көрсе, өзі де дәл солай жасаған болар еді - деп ғалым өз болжамын айтады (Мырзахметов, 198:. 245).

Әкім қазіргі жағдайды реттеп отырған заңмен келіспесе, онда ол бұрын қала әкімдері қолдаған және ескіден сақталып келген қоғамға пайдасы жоқ заңдарға жаңадан өзгерістер енгізеді. Оның өзінен бұрынғы әкімдердің бекіткен заңдарымен билікті жалғастыруы міндетті емес. Өзінен бұрынғы билеушілерден қалған заңдар негізінде қаланы билеуші әкім - ізбасар әкім.

\section{Қорытынды}

Қорыта келе әл-Фарабидің ойынша бірінші басшы болу үшін, мына жолдармен қол жеткізуге болады: алдымен адамда бәйекшіл ақылпарасат, содан кейін жүре келе пайда болатын ақыл-парасат қалыптасады, содан кейін, Аристотельдің «Жан туралы» еңбегінде айтылғандай, ол әрекетшіл ақыл-парасатпен бірігеді. Сондай адамды бұрынғылар нағыз әкім деген.

Әл-Фараби өзінің «Бақытқа жету» шығармасында басшылардың абыройы мен берері тең бола бермейді. Кейінгі басшылардың берекесі мына нәрселерді қамтиды: даналық, заң, ереже, әдет-ғұрыпты білу; тәртіпті орындау және орнықтыру, заң шығара алу, басқару өнерін меңгеру, билік күшін тиімді пайдалану деген ойын баяндайды.

Ғалымның ойындағы бірінші басшы - адамдардың арасындағы ең таңдаулы жан. Басшы тегінде, жалпы халыққа белгілі қарапайым біліммен әсте шектеліп қалмайды. Бірінші басшы, қасындағы кеңесшілері - жақсы қасиет пен білгірлік бойына дарыған азаматтар осындай болулары тиіс. Қолында азаматтық билігі бар әрбір азамат қоғам мүшелерінің қажеттерін өтеуге күш салады.

Әл-Фараби аңсаған бақытты қоғамның, насихаттаған басқару жүйесіне, пайымы мен осы логикасына тәсілдеріне қазір де зәруміз. Ғалымның сомдаған басшының бейнесі - үлгі. Мемлекеттік басқару, билік жүйесін жетілдіру, қоғам мүшелерін ізгілікке баулу қазір де қажет. 


\section{Әдебиеттер}

Arslan A. Mutluluğun kazanılması, (2012). (Tahsisus-Saada). Divan kitap, 100 sayfa.

Yaşar Aydınlı, (2017). Fârâbî, Bursa S 13.

Әл-Фараби, (1995). Китаб тахсиль әс-саьада. Бейрут-Любнан: Дар-уа-мактабатуль-хиляль, 102 б.

Әл-Фараби, (1996). Әс-Сияса әл-мадания. Бейрут-Любнан: Дар-уа-мактабатуль-хиляль, 127 б.

Yaşar Aydınlı. Fârâbî, (2017). Bursa, 13 б.

Әл-Фараби., (1995). Китаб тахсиль әс-саьада. Бейрут-Любнан: Дар-уа-мактабатуль-хиляль, 1026.

Әл-Фараби, (1996). Әс-Сияса әл-мадания. Бейрут-Любнан: Дар-уа-мактабатуль-хиляль, 127 б.

Әбу Насыр әл-Фараби, (2009). Таңдамалы трактаттары, Құраст.: Ә. Нысанбаев, Ғ. Құрманғалиева, Ж. Сандыбаев. Алматы: «Арыс» баспасы, 656 бет.

Ж. Сандыбаев, (2001), Ортағасыр шығыс философиясындағы басқару мәдениетінің адамгершілік негіздері: Монография. Астана: ҚР Президентінің жанындағы мемлекеттік басқару академиясы, 102 б.

Аль-Фараби, (1994), Избранные трактаты / Перевод с арабского. Алматы: ИФ АН РК, 440 с.

Әл-Фараби, (1995), Әро-у әхлу әл-мәдинати әл-фазилә. Бейрут-Любнан. Дар-уа-мактабатуль-хиляль, 198 б.

Әл-Фараби, (1996), Ихсау әл-Улуум. Бейрут-Любнан: Дар уа мактабату әл-хиләл, 34 б.

Әл-Фараби, (1975), Әлеуметтік-зтикалық трактаттар. А., 368 б.

Мырзахметов М., (1982), Мұхтар Әуезов және Абайтану проблемалары. Алматы: Ғылым, 245 бет.

Қелімбетов Н., (1986), Әбу Наср әл-Фараби. Алматы: Қазақ әдебиетінің ежелгі дәуірі, 79 бет.

Қоңыратбаев Ә., (1987), Фараби және Абай. Алматы: Қазақ эпосы және түркология, 336 бет.

Бурабаев М., (1988), Әл-Фараби, Қысқаша энциклопедия. Алматы: Қазақ ССР, 112 бет.

Yiğit H. El-Farabi., (2017), İstanbul: Maçivat yayınları, 76 sayfa.

Feyyaz S. (2009), Doğu İslam felsefesinin babası el-Farabi. İstanbul: Ağaç kitabevi, 48 sayfa.

Farabi, (2013), İdeal devlet (el-Medinetül- Fazıla) (Arslan A). - İstanbul: Divan Kitap, 327 sayfa.

Farabi, (2018), (el-Muallimus-Sani). Diyanet işleri başkanliği, 344 sayfa.

Farabi, (2017), Es-Siyasetül-Medeniyye veya Mebadiül-Mevcudat (Mehmet S). Büyüyenay, 128 sayfa.

Arslan A., (2012), Mutluluğun kazanılması (Tahsisus-Saada). Divan kitap, 100 sayfa.

Farabi, (2012), Üstün ülke el-Medinetül fazıla (Seyfi Say). Kurtuba kitap, 208 sayfa.

Farabi, (1999), İlimlerin Sayımı. Vadi yayınları, 104 sayfa.

\section{References}

Al-Farabi, (1995). Kitab tahsil as-saada. - Beyrut-Lubnan: Dar-ua-maktabatul-hilal, (1995). 102 b. Al-Farabi, (1996), As-siyasa al-madaniya. Beyrut-Lubnan: Dar-ua-maktabatul-hilal, (1996). 127 b. Abu Nasir al-Farabi, (1996), Tandamaly traktattar, Qurast.: A. Nisanbayev, G. Qurmangaliyeva, Zh. Al-Farabi, (1994), İzbrannie traktaty, Perevod s arabskogo. Almaty. İF AN RK, P. 440 .

Al-Farabi. (1995), Aro-u al-madinati al-fazila. Beyrut-Lubnan: Dar-ua-maktabatul-hilal, 198 b.

Al-Farabi, (1996), İhsau al-Uluum. Beyrut-Lubnan: Dar-ua-maktabatul-hilal, P. 34 .

Al-Farabi, (1975), Aleumettik-etikalyq traktattar. A.,368 b.

Mirzahmetov M. (1982), Mukhtar Auezov jane Abaytanu problemalary.Almaty: Gylym, 245 bet.

Kelimbetov N. (1986), Abu Nasir al-Farabi. Almaty: Qazaq adebiyetinin ejelgi dauiri, 79 bet.

Qonyratbayev A. (1987), Farabi jane Abay. -Almaty: Qazaq eposy jane turkologiya, 336 bet.

Burabayev M.,(1988), Al-Farabi . Qysqasha ensiklopediya. Almaty: Qazaq SSR, 112 bet.

Sandybayev. (2009), Almaty: "Arys” baspasy, 656 bet.

Feyyaz S., (2009), Doğu İslam felsefesinin babası el-Farabi. İstanbul: Ağaç kitabevi, 48 sayfa.

Farabi, (2013). İdeal devlet (el-Medinetül- Fazıla) (Arslan A). İstanbul: Divan Kitap, 327 sayfa.

Farabi, (2018), (el-Muallimus-Sani). Diyanet ișleri başkanliği, 344 sayfa.

Farabi, (2017), Es-Siyasetül-Medeniyye veya Mebadiül-Mevcudat (Mehmet S). Büyüyenay, 128 sayfa.

Arslan A., (2012), Mutluluğun kazanılması (Tahsisus-Saada). Divan kitap, 100 sayfa.

Farabi, (2012), Üstün ülke el-Medinetül fazıla (Seyfi Say). Kurtuba kitap, 208 sayfa.

Farabi, (1999), İlimlerin Sayımı. Vadi yayınları, 104 sayfa.

Yaşar Aydınlı, (2017), Fârâbî. Bursa, P.13.

Yiğit H. El-Farabi. (2017), İstanbul: Maçivat yayınları, 76 sayfa.

Sandybayev Zh. (2001), Ortagasyr shygys filosofiyasındagi basqaru madeniyetinin adamgershilik negizderi: Monografiya. Astana: QR Prezidentinin janindagi memlekettik basqaru akademiyasy, P. 102. 